\title{
ANALISIS PERKEMBANGAN SENI KREATIVITAS SISWA KELAS RENDAH MUHAMMADIYAH PAJANGAN 2 YOGYAKARTA
}

\author{
Fia Alifah Putri ${ }^{1}$, Rahmawati ${ }^{1}$ dan Suyadi ${ }^{1}$

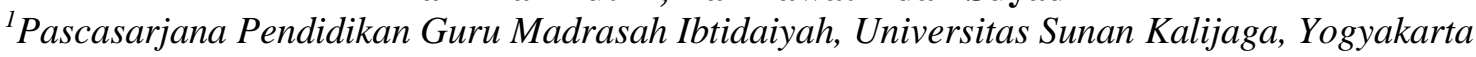 \\ fiaalifahputri24@gmail.com,yadi.uinjogja@gmail.com
}

Naskah diterima: 10 Oktober, 2019, direvisi: 20 Maret, 2020, diterbitkan: 31 Maret, 2020

\begin{abstract}
The purpose of this study was to find out how the process of the development of art and creativity of elementary age students and analyze the development of art and creativity of elementary students of class IIB at Muhammadiyah Elementary School 2 of Yogyakarta. Using a descriptive qualitative research approach, with a population of second grade students of Muhammadiyah Pajangan 2 Elementary School Yogyakarta, amounting to 40 students, and the sample that the researcher used was a non probality sample with a purposive sampling technique and analyzed descriptive. Based on the results of the study obtained conclusions that the results of the analysis of the development of art and creativity of students of class IIB Muhammadiyah Elementary School 2 of Yogyakarta show that it has been achieved and fulfilled all in accordance with the indicators of creativity achievement of elementary age students. Creativity and art are interrelated because creative is a process of thinking and art that is the result of creating a new thing.
\end{abstract}

Keywords: Creativity, Development, and Art.

\begin{abstract}
ABSTRAK
Tujuan dari penelitian ini adalah untuk mengetahui bagaimana proses perkembangan seni dan kreativitas siswa usia dasar serta menganalisis perkembangan seni dan kreativitas siswa usia dasar kelas II B di SD Muhammadiyah Pajangan 2 Yogyakarta. Menggunakan pendekatan penelitian kualitatif deskriptif, dengan populasi siswa kelas II SD Muhammadiyah Pajangan 2 Yogyakarta yang berjumlah 40 siswa, dan sampel yang peneliti gunakan adalah non probality sampel dengan teknik purposive sampling dan dianalisis secara deskriptif. Berdasarkan hasil penelitian diperoleh simpulan bahwa hasil analisis perkembangan seni dan kreativitas peserta didik kelas IIB SD Muhammadiyah Pajangan 2 Yogyakarta menunjukkan bahwa telah tercapai dan terpenuhi semua sesuai dengan indikator pencapaian kreativitas siswa usia dasar. Kreativitas dan seni saling berkaitan karena kreatif adalah proses dari pemikiran dan seni adalah hasil sehingga menciptakan suatu hal yang baru.
\end{abstract}

Kata Kunci: Kreativitas, Perkembangan, dan Seni

\section{PENDAHULUAN}

Perkembangan secara alamiah setiap anak berbeda-beda ada anak yang memiliki pola perkembangan yang cepat, normal ataupun lambat. Perkembangan itu juga berbeda-beda yaitu perkembangan kognitif, fisik-motorik, bahasa seni, kematangan emosi, kepribadian keadaan jasmani dan sosialnya. Selain itu setiap anak memiliki kemampuan yang tak terbatas untuk mengembangkan dirinya dalam berkreasi dan produktif atau menciptakan hal yang baru.

Kemampuan-kemampuan seperti itu bisa kita dapatkan salah satunya melalui pendidikan. Menurut Azhari (2013) menyatakan bahwa pendidikan menentukan perkembangan serta perwujudan sumber daya manusia khususnya pada pembangunan bangsa dan negara. Pendidikan memiliki peranan yang penting dalam membentuk sumber manusia yang cerdas, cakap, kreatif, beriman dan berakhlak mulia. Hal tersebut juga tertuang 
dalam tujuan pendidikan nasional yang mengharapkan pendidikan dapat mengembangkan potensi peseta didik agar bertakwa, berbudi luhur, berilmu, cerdas, kreatif, melek teknologi serta berakhlak mulia.(Sekar, 2017).

Pernyataan tersebut diperkuat oleh A. Sudiarja (2018) yang membahas Undang Undang No.20 tahun 2003, bab II pasal 3 menyatakan berkembangnya potensi peserta didik agar menjadi manusia yang beriman dan bertakwa kepada Tuhan Yang Maha Esa, berakhlak mulia, sehat, berilmu, cakap, kreatif, mandiri dan menjadi warga negara yang demokratis serta bertanggung jawab (Sudiarja, 2018). Dalam UU No.20 tahun 2003 tersebut pemerintah menyatakan bahwa peserta didik haruslah memiliki jiwa kreatif. Kreatif memiliki peranan yang penting dalam perkembangan otak anak, karena kreatif juga mampu meningkatkan kognitif anak juga kecerdasannya. Hakikatnya perkataan kreatif adalah penemuan sesuatu yang baru dan bukan akumulasi dari keterampilan atau pengetahuan yang diperoleh dai buku pelajaran. Kreatif diatikan juga sebagai pola berpikir atau ide yang timbul secara spontan dan imajinatif, yang mencerminkan hasil-hasil ilmiah, penemuan ilmiah, dan penciptaanpenciptaan secara mekanik (Muhammad, 2016).

Kreativitas menurut Santrock (2002) yaitu suatu kemampuan untuk memikirkan sesuatu dengan segala cara yang baru dan tidak biasa serta melahirkan suatu solusi yang unik terhadap masalah-masalah yang dihadapi. Kreativitas menuntut suatu hal yang unik atau yang baru diperbuat oleh anak tersebut, hal ini senada dengan ciri anak usia dini yaitu mereka memiliki sifat rasa ingin tahu yang besar, setelah mereka mengetahui selanjutnya mereka akan masuk pada tahap yang lebih tinggi yaitu mencipta sesuatu hal yang baru. Sesuai dengan yang dikatakan Drevdahl (dalam Hurlock, 1978) yang mengungkapkan bahwa kreativitas adalah kemampuan seseorang untuk menghasilkan produk, komposisi, atau gagasan apa saja yang pada dasarnya hal tersebut baru dan sebelumnya tidak dikenal pembuatnya (Hurlock, 1978:4).

Peserta didik dikatakan kreatif jika melakukan suatu pemecahan masalah melalui cara yang berbeda atau tidak seperti biasanya. kreativitas merupakan hasil dari kerjasama otak kanan dan otak kiri. Kedua otak ini menggabungkan kinerja imajinasi dan kondisi riil atau kondisi yang sesungguhnya sehingga tercipta sesuatu yang baru. Kreativitas itu adalah $1 \%$ ide yang merupakan pemikiran dan $99 \%$ aksi yaitu sebuah tindakan seperti yang dikatakan oleh Andi Yudha Asfandiyar seorang pemerhati dan praktisi dunia anak (Andi, 2016).

Kreativitas memiliki manfaat besar bagi kehidupan dan jiwa anak, yaitu a) dengan kreativitas memberi anak-anak kesenangan dan kepuasaan pribadi yang sangat besar penghargaannya untuk perkembangan kepribadiannya sendiri, karena mereka dapat menciptakan sesuatu sendiri, b) menjadi seorang yang kreatif adalah hal yang penting bagi anak karena akan membuat permainannya menyenangkan merasa bahagia dan puas, c) prestasi merupakan kepentingan utama dalam hidup mereka, maka kreativitas membantu mereka untuk mencapai keberhasilan di bidang yang berarti bagi mereka, d) nilai kepemimpinan maka anak akan belajar memberi usulan atau bagaimana bertanggung jawab sebagai pemimpin di kelompok bermainnya dan berkreativitas (Andi, 2016). Karena kreativitas sebagai suatu proses rasionalisasi maksudnya adalah bahwa kreativitas itu merupakan hasil dari pemikiran yang kreatif. Sedangkan bakat kreatif berarti proses rasionalisasi atau ia merupakan produk akal. Anak yang berbakat memiliki keistimewaan dan kapabilitas tertentu atau yang sering disebut sebagai bakat alamiah yang diciptakan khusus oleh Allah SWT (Amal, 2006).

Sedemikian pentingnya pengembangan kreativitas terutama pada jenjang peserta didik usia muda, yang kita pahami usia kelas awal SD adalah seusia emas (golden age) yaitu pada rentang usia dari 6 tahun sampai 8 tahun, dimana semua potensi akan berkembang sangat 
pesat pada masa itu (Mohamad, 2016). Dan juga peningkatan sumber daya manusia dalam era globalisasi dan era reformasi menunjukkan betapa pentingnya segi kreativitas diprioritaskan untuk dikelola dan dikembangkan secara optimal dan hal ini merupakan tantangan kepedulian serius bagi pihak terkait dalam pengembangan sumber daya manusia, terutama dikalangan pendidikan, karena pendidikan itu sangat penting (Mohamad, 2016).

Kecerdasan dalam berkreativitas yang disebut dengan Cretivity Quotient. Ini merupakan salah satu ranah dalam intelegensi dan merupakan suatu potensi seseorang dalam menciptakan sesuatu. $C Q$ diperkenalkan oleh Guil Ford. Kreativitas berhubungan dengan intelegensi seperti yang telah diungkapkan oleh Hurlock. Dikatakan berhubungan karena keduanya menjurus kepada penciptaan sesuatu yang baru bergantung pada kemampuan untuk mendapatkan pengetahuan yang sudah umum diterima, pengetahuan tersebut kemudian diatur dan diolah ke dalam bentuk baru yang orisinal, ia menggunakan pengetahuan yang diterima sebelumnya dan ini bergantung pada kemampuan intelektual seseorang.

Misalnya cara mendidik anak yang sangat otoriter di rumah atau di sekolah selama bertahun-tahun maka pembentukan awal anak akan membuat anak tersebut membekukan kreativitasnya tetapi tidak mempengaruhi kecerdasan tinggi. Dalam kondisi demikian hubungan antara integensi dan kreativitas akan rendah. Jadi, bila tidak ada hambatan yang mengganggu perkembangan kreativitas anak, cukup aman untuk mengatakan bahwa semakin cerdas anak maka semakin dapat ia menjadi kreatif (Elizabeth, 1978).

Berangkat dari permasalahan tersebut maka peneliti ingin mengetahui bagaimana proses perkembangan seni dan kreatifitas siswa pada kelas II B pada SD Muhammadiyah Pajangan 2 Yogyakarta apakah sudah terpenuhi apa belum dan bagaimana analisis perkembangan seni dan kreatifitas siswa pada kelas II B SD Muhamadiyah Pajangan 2 Yogyakarta tersebut dengan cara dianalisis sesuai dengan indikator yang telah ditetapkan

Penelitian ini didukung oleh beberapa penelitian yang relevan seperti penelitian mengenai kreativitas dan seni siswa usia dasar yang dilakukan oleh Dewi Widiana Rahayu yang dimuat dalam Proceidings of The Icecrs Volume 1 No.3 pada tahun 2018 yang berjudul "Penerapan Model Pembelajaran Langsung Untuk Meningkatkan Kreativitas Anak Sekolah Dasar". Hasil dari penelitiannya adalah peningkatan kreativitas siswa juga sangat dipengaruhi dengan kesiapan alat dan bahan yang diupayakan pada proses pembelajaran berlangsung (Dewi, 2018) Didukung pula oleh penelitian yang dilakukan oleh Ade Holis yang berjudul "Belajar Melalui Bermain untuk Pengembangan Kreativitas dan Kognitif Anak Usia Dini" yang dimuat dalam Jurnal Pendidikan Universitas Garut volume 09 No 1 pada tahun 2016. Dari hasil penelitian tersebut dapat disimpulkan bahwa kelas yang diberikan perlakuan menggunakan pembelajaran melalui bermain balok menghasilkan peningkatan kreativitas yang signifikan daripada kelas yang tidak diberi perlakuan (Ade, 2016).

Perbedaan penelitian yang dilakukan oleh peneliti sebelumnya, yaitu pada penelitian pertama membahas kreativitas dengan pembelajaran langsung sedangkan pada penelitian yang kedua membahas kreativitas yang dikaitkan dengan belajar sambil bermain. Sedangkan pada penelitian ini peneliti akan melakukan penelitian yang menggabungkan keduanya yaitu menggabungkan antara kreativitas seni dengan belajar secara langsung sambil bermain.
a. Kondisi yang Meningkatkan Kreativitas
Peningkatan kreativitas peserta didik dapat terjadi dengan adanya kondisi-kondisi tertentu yaitu sebagai berikut (Elizabeth, 1978): 
Waktu, menjadi kreatif adalah dengan tidak mengatur kegiatan anak sedemikian rupa sehingga hanya sedikit waktu bebas bagi mereka untuk bermain-main dengan gagasan dan konsep-konsep dan mencobanya dalam bentuk baru atau orisinal. Kesempatan menyendiri, hanya apabila tidak mendapat tekanan dari kelompok sosial yang lain, anak dapat menjadi kreatif, Singer menerangkan anak membutuhkan waktu dan kesempatan menyendiri untuk mengembangkan kehidupan imajinatif yang kaya.

Dorongan, terlepas dari seberapa jauh prestasi anak memenuhi standar orang dewasa, mereka harus didorong untuk keatif dan bebas dari ejekan dan kritik yang sering kali dilontarkan pada anak yang kreatif. Sarana, untuk bermain anak dan sarana lainnya harus disediakan untuk merangsang dorongan eksplorasi atau eksperimentasi anak yang merupakan unsur penting dari semua kreativitas anak. Lingkungan yang dapat merangsang kreatif, lingkungan rumah dan sekolah harus merangsang kreativitas anak dengan cara memberikan anak bimbingan dan dorongan menggunakan sarana yang akan mendorong kreativitas dengan menjadikan kreativitas suatu pengalaman yang menyenangkan dan dihargai secara sosial untuk meningkatkan kreativitas anak.

Hubungan orang tua anak yang tidak posesif, orang tua yang tidak terlalu posesif atau tidak terlalu melindungi terhadap anak, mendorong anak untuk mandiri dan percaya diri, dua kualitas yang sangat mendukung kreativitas. Cara mendidik, mendidik anak secara demokratis dan permisif yaitu memberikan kebebasan dengan tetap dikontrol dan terbuka dirumah dan sekolah akan meningkatkan dan mendorong kreativitas anak sedangkan cara mendidik anak secara otoriter atau mengekang dapat memadamkan kreativitasnya. Kesempatan untuk memperoleh pengetahuan, kreativitas tidak muncul dalam keadaan kehampaan semakin banyak pengetahuan yang dapat diperoleh anak semakin baik dasar mencapai hasil yang kreatif. Pulaski mengatakan anak-anak harus berisi pemikirannya agar dapat berfantasi.

\section{b. Penghambat Kreativitas Anak}

Pentingnya pengembangan kreativitas dilakukan sejak usia dasar, dikatakan demikian karena setiap peserta didik dilahirkan dengan adanya potensi kreatif di dalam diri mereka. Rachmawati (2012) menjelaskan persoalan yang terjadi pada perkembangan selanjutnya menyebabkan daya kreatif anak semakin berkurang. Peraturan-peraturan, pola kebiasaan, pola penghargaan, dan pola asuh orang dewasa di sekitar anak tersebut (Ni Made, 2016). Hal ini diperkuat oleh salah satu pemerhati anak yang menjelaskan bahwa kreativitas seorang anak tidak dapat berkembang secara optimal karena beberapa faktor penghambat antara lain:

1. Terlalu banyak larangan, larangan secara otomatis menghambat pengalaman belajar. Jika pengalaman belajar terlambat, kreativiats tidak akan bisa berkembang.

2. Memaksakan hanya satu cara, yang mungkin sudah out of date.

3. Kurang menghargai karya anak, sehingga anak berhenti berkarya. Padahal, penghargaan bisa diberikan melalui cara yang paling sederhana, seperti sapaan, pelukan, senyuman dan pujian.

4. Kurang mengembangkan humor dalam proses pembelajaran. Humor tidak saja membuat relaks, tapi juga menyehatkan fisik dan mental.

5. Terlalu banyak komentar negative atau kritik.

6. Kurangnya pembiasaan membaca dirumah atau literasi.

7. Adanya pewarisan kebiasaan buuk yang ditularkan orang tua kepada anak.

Sistem pendidikan yang hanya mengedepankan aspek kognitif menjadikan anak seperti robot, hanya diisi dengan sejumlah data yang sewaktu-waktu bisa di-recall. Tapi ingat, robot tidak mampu memecahkan masalah-masalah baru. Dan orang-orang seperti 
robot inilah yang disebut pintar, yang sayangnya tidak kreatif dan tak memiliki seni (Andi, 2016)

\section{c. Ciri-Ciri Kreativitas}

Menurut salah satu pemerhati anak Indonesia ciri- ciri orang kreatif antara lain adalah berani mencoba hal baru, punya rasa ingin tahu yang tinggi, tidak takut salah atau gagal, punya banyak alternatif atau solusinya, banyak membaca dan mencari hal baru, punya selera humor yang tinggi, tidak meremehkan hal-hal kecil dan orang lain berani berbeda, selalu mencatat atau merekam ide-ide yang ditemukan dan tidak sabar merealisasikan ide-idenya tersebut (Andi, 2016).

Sedangkan menurut pendapat Sund yang dikutip Slameto (2003) mengatakan ciri-ciri individu yang memiliki ciri-ciri kreatif yang harus dipahami guru tehadap setiap siswanya antara lain adalah sebagai berikut:

1. Hasrat keingintahuan yang besar

2. Terbuka terhadap pengalaman baru

3. Panjang akal

4. Keinginan untuk menemukan dan meneliti

5. Lebih menyukai tugas yang berat dan sulit

6. Mencari jawaban yang luas dan memuaskan

7. Aktif dalam melaksanakan tugas

8. Berfikir fleksibel

9. Menggapai pertanyaan serta cenderung memberikan jawaban lebih banyak

10. Kemampuan membuat analisis dan sintesis

11. Memiliki semangat bertanya

12. Daya abstraksi yang cukup baik

13. Memiliki latar belakang membaca yang cukup luas.

\section{METODOLOGI}

Metode penelitian pada penelitian ini menggunakan penelitian kualitatif deskriptif. Dengan pengumpulan data menggunakan triangulasi yang terdiri dari wawancara, observasi dan dokumentasi. Sumber data penelitian yang peneliti gunakan dalam penelitian ini meliputi populasi dan sampel. Populasi dalam penelitian ini adalah siswa kelas II B SD Muhamadiyah Pajangan 2 Yogyakarta yang berjumlah 112 siswa. Dan sampel yang peneliti gunakan adalah non probality sampel dengan teknik purposive sampling yang merupakan teknik penentuan sampel dengan pertimbangan-pertimbangan tertentu (Karunia, 2017).

Adapun petimbangan yang peneliti butuhkan adalah kelas yang memiliki karakteristik sesuai dengan teori periode kritis dalam perkembangan kreativitas usia 8-10 tahun yang merupakan usia yang memiliki tingkat kreativitas yang tinggi. Berdasarkan pertimbangan yang peneliti butuhkan ini, maka peneliti menetapkan kelas II B yang berjumlah 20 siswa sebagai kelas yang akan diteliti. Lalu hasil penelitian ini dianalisis dengan menggunakan analisis deskiptif yaitu mendeskripsikan data yang telah terkumpul sebagaimana adanya.

Wawancara dilakukan terhadap wali kelas dan peserta didik kelas IIB SD Muhammadiyah Pajangan 2 Yogyakarta untuk memperoleh data mengenai perkembangan seni dan kreativitas. Sedangkan observasi dilakukan untuk mengamati aktivitas perkembangan peserta didik didalam kelas pada saat proses pembelajaran. Dokumentasi digunakan untuk memperkuat hasil dari pengumpulan data yang digunakan dalam penelitian ini. 
Adapun analisis deskriptif yang digunakan pada penelitian ini adalah menganalisis indikator kreativitas. Yang dimana indikator ini merupakan suatu bahasan mengenai tolak ukur atau sudah sampai sejauh mana tolak ukur suatu perkembangan kreativitas tersebut telah terpenuhi. Menurut Sund (Riyanto, 2002) menyatakan bahwa individu dengan potensi kreatif yaitu:

1. Keinginan siswa untuk melakukan tindakan dan rencana yang inovatif setelah difikirkan matang-matang.

2. Percaya diri dan imajinatif untuk menemukan dan meneliti sesuatu dalam pembelajaran.

3. Memiliki dedikasi bergairah serta aktif dalam melaksanakan tugas dan menanggapi pertanyaan yang diajukan serta cenderung memberikan jawaban yang lebih banyak.

4. Kemampuan membuat analisis dan sintesis (Agus, 2015)

\section{HASIL DAN DISKUSI}

Perkembangan seni dan kreativitas ini mengamati subjek yaitu kelas II B yang berjumlah 20 orang, terdiri dari 12 orang laki-laki dan 8 orang perempuan. Pengamatan dan analisis dilakukan pada saat materi SBdP yaitu "Memahami Prakarya dari Bahan Buatan" dalam pembelajaran SBdP ini anak-anak ditugaskan untuk membuat maket dalam bentuk kebun binatang. Mereka diminta melakukan semuanya secara berkelompok namun masingmasing dari mereka memiliki tugas masing-masing. Mereka diminta untuk membawa barang-barang yang diperlukan untuk pembuatan maket kebun binatang, seperti: Lidi, lem, cat air, kuas, kertas, gunting, pensil dan kardus. Sedangkan ibu guru wali kelas membawa sterofom.

Maket dibuat dengan yang pertama yaitu menggambar atau menulis garis-garis gambaran yang berbentuk aneka hewan atau pepohonan kemudian pola tersebut disisi sebelahnya diberi warna atau dilukis selanjutnya bagian bawahnya di kasih lidi dengan cara ditusuk agar dapat berdiri di atas sterofom. Kemudian aneka hewan dan pepohonan tersebut dibuat berdiri dengan cara lidi ditusuk selanjutnya anak-anak diminta untuk menghiasi maket tersebut, membuat pagar, pintu masuk dan lain sebagainya. Mereka membuat dengan senang hati dan penuh bergairah, bahkan imajinasi mereka bermain saat membuat maket. Pembuatan maket memerlukan imajinasi dan mereka membuat maket dengan seni, bermacam-macam pagar yang dibuat oleh mereka. Ibu guru memberikan kesempatan sepenuhnya untuk mereka berkreasi dan seni berkarya.

Maket tersebut membuat anak-anak bebas untuk berkarya membuat maket dengan seni karya tangan mereka. Maket menuntut anak-anak untuk berkreasi dan dituntut untuk memiliki seni dan kreativitas. Kreativitas adalah suatu proses bukan hasil. Proses bagaimana anak-anak dapat melakukan segala sesuatu yang tercipta dari tangan mereka sendiri dengan menggunakan seni. Menurut Sumanto kreativitas seni adalah kemampuan untuk menciptakan, menemukan, membuat merancang ulang dan memadukan suatu gagasan baru maupun lama menjadi kombinasi baru yang dipadukan pada akhirnya terkomposisi atau terpadu menjadi karya seni dengan di dukung kemampuan terampil yang dimiliki anak tersebut (Masganti, 2016). Sesuai dengan yang telah dilakukan oleh anak-anak kelas IIB yang mana mereka dituntut untuk menciptakan maket dengan keterpaduan keterampilan yang dimilikinya, keterampilan dalam menggunting, menggambar, dan lain-lain.

Pada usia 7-11 tahun dalam ilmu kognitif diketahui bahwa anak masuk dalam periode konkret, ini sesuai dengan usia anak-anak kelas II B. Periode konkret ditandai dengan pemikiran bahwa anak sudah mampu menggunakan operasi atas segala sesuatu tidak lagi hanya mengamati, pemikiran anak tidak lagi didominasi oleh persepsi karena anak sudah 
mampu memecahkan masalah secara logis mandiri. Ini terlihat ketika ibu wali kelas memberikan prosedur saat sebelum memulai pekerjaan, wali kelas hanya memberi arahan tentang apa yang harus dilakukan oleh mereka seperti menggambar, menggunting, melem. Mereka melakukan sesuai dengan instruksi oleh wali kelas. Kemudian mereka melakukan sendiri. Wali kelas hanya mendampingi dan mengontrol apa yang mereka lakukan.

Anak-anak kelas II B dominannya sudah memiliki seni dan jiwa kreatif seperti yang telah dijelaskan oleh Ibu wali kelas II B yaitu:

Anak-anak kelas II B memang anak-anak yang luar biasa mereka kadang sulit di atur, kelas sering dibuat ribut oleh satu dua anak yang kemudian mengundang keributan anak-anak yang lain. Namun mereka itu manis-manis, mereka sebenarnya adalah anakanak yang baik dan kadang dengan cara membuat onar itu, sebenarnya mereka ingin mencari dan minta perhatian saya sebagai wali kelas. Mereka semua sangat senang jika saya ajak melakukan sebuah proyek atau pembelajaran yang langsung mereka sendiri melakukan atau mempraktekkan sendiri. Mereka sangat antusias dan hasilnya semua memang bisa berkreasi dengan seni melalui tangan mereka sendiri, mereka semua yang menempel, menggunting, melem, menggambar dan mengkreasikan sendiri membuat menjadi sebuah kebun binatang. Memang ada yang masih setengah-setengah rapinya ada yang benar-benar rapi dalam melakukannya namun terlepas dari semua itu mereka semua telah berhasil untuk melakukan apa yang saya perintahkan yaitu membuat maket, dari team work tersebut mereka juga dapat lebih memahami arti tanggung jawab terhadap pekerjaan kelompok, berbagi ketika ada kelompok teman yang tidak membawa kardus, memaknai waktu, membantu ketika ada teman yang perlu bantuan. Saya sebagai wali kelas mereka sangat senang melihat team work mereka juga hasil karya mereka, iya walaupun masih ada yang berantakan namun itulah hasil tangan mereka dan sesuai dengan usia mereka yang masih kelas rendah.

Ketercapaian kreativitas dan seni dilihat dari indikator kreativitas yang telah ditetapkan, indikator sebagai titik temu dalam menentukan apakah sudah tercapai atau belum, secara umum seperti yang telah dilakukan dan diteliti SD Muhammadiyah Pajangan 2 kelas IIB sudah tecapai tingkat kreativitas mereka, analisisnya sebagai berikut:

Indikator yang pertama adalah dilihat dari keinginan siswa untuk melakukan tindakan dan rencana yaitu dalam pembuatan maket, yang hasilnya mereka sangat antusias menanggapi tentang pembuatan maket, dari pembuatan hingga maket tersebut telah selesai mereka membuat dengan inovatif juga telah difikirkan matang-matang. Mereka akan membawa bahan-bahan apa dan menggambar binatang- binatang serta pohon dan bunga apa yang digunakan. Selanjutnya yang kedua yaitu terlihat mereka semua sangat percaya diri dalam melakukan tugasnya masing-masing. Mereka menggunting, menggambar dan melukis dengan cat warna, mereka juga menggambar dengan imajinatif dan menemukan sendiri sesuatu yang baru juga cara kerja, hanya dengan arahan mereka dapat menemukannya. Mereka juga meneliti sesuatu dalam pembelajaran contohnya bagaimana caranya membuat maket sendiri.

Dalam pepatah Tiongkok mengatakan bahwa "jika saya mendengar maka saya lupa, jika saya melihat maka saya ingat dan jika saya melakukan maka saya paham" itulah yang mereka alami, mereka melakukan pembelajaran dengan active learning yaitu mereka akan lebih mudah memahami jika mereka diajak untuk melakukan sesuatu dan berkreasi sesuai dengan imajinasi mereka. Karena kreatif itu adalah pemikiran di otak sedangkan seni adalah hasil pemikiran tersebut yang pada nantinya akan menghasilkan suatu karya. Jadi kreatif dan seni adalah satu kesatuan yang saling berhubungan. 
Indikator selanjutnya adalah anak-anak memiliki dedikasi yang bergairah serta aktif dalam melaksanakan tugas yang telah diperintahkan oleh guru. Anak juga menanggapi pertanyaan yang diajukan serta cenderung memberikan jawaban yang lebih banyak. Jika kita bertanya maka mereka akan menjawab sesuai dengan pola pikiran mereka. Contohnya ketika ibu guru bertanya "ini hewan apa?" (sambil menunjukkan gambar ikan) anak menjawab "ini gambar ikan" dan menerangkan bahwa dia akan membuat danau menggunakan cat air agar ikan tersebut dapat hidup di dalam air. Karena ikan habitatnya di air.

Indikator kreativitas peserta didik yang terakhir adalah peserta didik mampu membuat analisis dan sintesis. Seperti peserta didik di proses pembelajaran menganalisis dan menyimpulkan bahwa hewan-hewan apa saja yang terdapat dikebun binatang dan tidak ada dikebun binatang serta mereka bekreasi dengan tata letak gerbang pintu masuk dan tata letak gerbang pintu keluar. Serta mereka mengkreasikan maket menggunakan pagar yang di desain dengan hasil pemikiran kelompok mereka. Berdasarkan hasil analisis perkembangan seni dan kreativitas peserta didik kelas IIB SD Muhammadiyah Pajangan 2 Yogyakarta menunjukkan bahwa telah tercapai semua indikator pencapaian kreativitas siswa dasar.

\section{KESIMPULAN}

Hakikatnya kreatif adalah penemuan sesuatu yang baru dan bukan akumulasi dari keterampilan atau pengetahuan yang diperoleh dari buku pelajaran. Kreatif diartikan juga sebagai pola berpikir atau ide yang timbul secara spontan dan imajinatif, yang mencerminkan hasil-hasil ilmiah, penemuan ilmiah, dan penciptaan-penciptaan secara mekanik. Indikator ketercapaian untuk kreativitas dan seni adalah yaitu 1). Keinginan siswa untuk melakukan tindakan dan rencana yang inovatif setelah difikirkan matang-matang. 2) percaya diri dan imajinatif untuk menemukan dan meneliti sesuatu dalam pembelajaran. 3) Memiliki dedikasi bergairah serta aktif dalam melaksanakan tugas dan menanggapi pertanyaan yang diajukan serta cenderung memberikan jawaban yang lebih banyak. 4) Kemampuan membuat analisis dan sintesis. Berdasarkan hasil analisis perkembangan seni dan kreativitas peserta didik kelas II B SD Muhammadiyah Pajangan 2 Yogyakarta menunjukkan bahwa telah tercapai semua indikator pencapaian kreativitas siswa dasar.

\section{BIBLIOGRAPHY}

Abdussalam Al-Khalili, Amal. Mengembangkan Kreatifitas Anak. Jakarta: Pustaka AlKautsar. 2006.

Ardianti, Sekar Dwi dkk, Implementasi Project Based Learning (PBL) Berpendekatan Science Edutaiment Terhadap Kreativitas Peserta Didik, Jurnal Refleksi Edukatika, 2017, Vol.7, No.2, p-ISSN:2087-9385, e-ISSN:2528-696X

Asfandiyar, Andi Yudha, 2016, Creative Parenting Today, Bandung: PT Mizan Pustaka.

Ayu Suryaningsih, Ni Made. dkk, Implementasi Pembelajarran Inkuiri Terbimbing Berbasis Permainan Dalam Meningkatkan Kreativitas Anak Usia Dini, Jurnal Pendidikan Indonesia, Vol.5, No.2, Oktober 2016.

Eva Flora Siagian, Roida dan Maya Nurfitriyani, Metode Pembelajaran Inquiry dan Pengaruhnya Terhadap Hasil Belajar Matematika Ditinjau Dari KreatifitasBelajar, Jurnal Formatif, Vol.2 No 1, ISSN:2088-35IX.

Holis, Ade. Belajar Melalui Bermain untuk Pengembangan Kreativitas dan Kognitif Anak Usia Dini, Jurnal Pendidikan Universitas Garut, vol. 09, No.1, 2016

Hurlock, Elizabeth. Perkembangan Anak Jilid 2 Edisi Keenam. Jakarta: Erlangga. 1978. 
Idris Usman, Muhammad. Pengaruh Kreativitas dan Motivasi Belajar Siswa Terhadap Prestasi Belajarr Bahasa Aab di MA DDI Al-Badar, Jurnal Lentera Pendidikan, Vol.19, No.1, Juni 2016.

Lestari, Karunia Eka, 2017, Penelitian Pendidikan Matematika, Bandung: PT Refika Medika

Makmur, Agus, Efektifitas Penggunaan Metode Base Method Dalam Meningkatkan Kreativitas dan Motivasi Belajar Matematika Siswa SMPN 10 Padangsidimpuan, Jurnal Edu Tech, Vol.1 No 1 Maret 2015, ISSN: 2442-6024, e-ISSN: 2442-7063

Masganti, Sit. 2016, Pengembangan Kreativitas Anak Usia Dini (Teori dan Praktek), Medan: Perdana Publishing

Rahayu, Dewi Widiana, 2018, Penerapan Model Pembelajaran Langsung Untuk Meningkatkan Kreativitas Anak Sekolah Dasar, Proceedings of The ICECRS, Vol.1 No.3

Sudiarja, A, 2018, Pendidikan Dalma Tantangan Zaman, Yogyakarta: PT Kanisius

Sumantri, Mohamad Syarif, Asesmen Dan Intervensi Pedagogik Dalam Membangun Generasi Emas Ditinjau Dari Perspektif Pengembangan Kreativitas Siswa Kelas Awal Sekolah Dasar, Jurnal Pendidikan Dasar, Vol.7 No.1, Mei 2016. 